\title{
TEXTBOOK EVALUATION ACCORDING TO OUTCOME-BASED EDUCATION (OBE) PRINCIPLES
}

\author{
Leoni Damayanti ${ }^{1}$, Ive Emaliana ${ }^{2,{ }^{*}}$, Irene Nany Kusumawardani ${ }^{3}$ \\ ${ }^{1}$ English Education Department, Faculty of Cultural Studies, University of Brawijaya Malang, Malang 65142, \\ Indonesia \\ ${ }^{2}$ English Education Department, Faculty of Cultural Studies, University of Brawijaya Malang, Malang 65142, \\ Indonesia \\ ${ }^{3}$ English Education Department, Faculty of Cultural Studies, University of Brawijaya Malang, Malang 65142, \\ Indonesia
}

\section{ARTICLE INFO}

Keywords:

Extensive reading

Outcome-based education

Reading skill

Textbook evaluation

Article History:

Received: 07/09/2020

Accepted: 22/05/2021

Available Online:

$31 / 05 / 2021$

\begin{abstract}
A B S T RACT
Outcome-Based Education (OBE) is known as the new curriculum that seeks students' outcomes after learning about the materials. According to that, an evaluation through the textbook, as the most-used source in teaching English, especially in Extensive Reading, is needed. The purpose of this paper is to identify whether the textbook is suitable or not based on the OBE principles. Moreover, some capable lecturers participated in evaluating this textbook using a reliable checklist. This research used a descriptive quantitative method with the results showed that in terms of module contents, this textbook is 'very poor,' in terms of module language items, this textbook is 'poor,' then in terms of module presentation expediency, this textbook is 'very poor.' The findings of this study pointed out many lacks of the textbook that need improvement.
\end{abstract}

2442-305X / (C) 2021 The Authors, this is open access article under the (CC-BY-NC) license (https://creativecommons.org/licenses/by-nc/4.0/), DOI: 10.19105/ojbs.v15i1.3778

\footnotetext{
* Corresponding Author:

Email address: ive@ub.ac.id (I. Emaliana)
}

\section{A. Introduction}

In the field of education, there are many media that can be utilized as the support system for the learners' learning process. In language teaching, textbook is one of the essential support systems which is mainly considered as source of knowledge. $^{1}$ Besides, Wright ${ }^{2}$ describes that textbook is designed as an

1 Jack C. Richards, Curriculum Development in Language Teaching (Cambridge: Cambridge University Press, 2001), 254; Ye Sun and Thi Ngoc Yen Dang, "Vocabulary in High School EFL Textbooks: Texts and Learner Knowledge," System 93 (2020): 102-279, https://doi.org/10.1016/j.system.2020.102279. 
instructional media for teachers and students to achieve learning outcomes. Notably, in English as a foreign language (EFL) teaching, a textbook has been an inevitable part of English language teaching and learning media that contains materials, tasks, and evaluation based on determined learning objectives. ${ }^{3}$ As a pivotal element for reaching the aims of learning English, a textbook can function as an independent study guide since students can study by themselves the materials and tasks prior to or following the classroom activities. ${ }^{4}$ In other words, teachers use textbooks to keep their teaching on the topic and to meet learning goals when teaching.

The teaching of EFL requires textbooks to facilitate learning to attain English competence. Sheldon declared that textbook is a key to gain the students' linguistic and communication skills in using EFL. ${ }^{5}$ Besides, Cunningsworth mentions that textbooks facilitate not only exploring their ideas and creativities but also guiding teachers who have less

\footnotetext{
${ }^{2}$ Wright cited by C.Y. Lee and Hsien-Chin Liou, "A Study of Using Web Concordancing for English Vocabulary Learning in a Taiwanese High School Context," English Teaching \& Learning 27 (2003): 35-56.

${ }^{3}$ Martin Cortazzi and Lixian Jin, "Cultural Mirrors: Materials and Methods in the EFL Classroom," in Culture in Second Language Teaching and Learning, ed. Eli Hinkel (Cambridge: Cambridge University Press, 1999), 588.

4 Hayati Wasistyo Adi and Puji Astu ti, "Content Analysis of Student Book When English Rings A Bell (Revised Edition) for Grade VIII of Junior High School," ELT Forum: Journal of English Language Teaching 8, no. 1 (2019): 49-59, https://doi.org/10.15294/elt.v8i1.26138.

5 Lee Sheldon, "Evaluating ELT Textbooks and Materials," ELT Journal 42, no. 4 (1988): 237-46.
}

experience and bring them their confidence in teaching. ${ }^{6}$ In addition, Ivić states that textbooks provide information about a clearly defined circle of users, level of education, age, and field of education when learning EFL. ${ }^{7}$ Thus, a textbook is a comprehensive compilation material of specific study for learners to facilitating both students and teachers in achieving certain competence, especially in an EFL setting.

However, to identify the proper EFL textbook that suits the need of students and teacher is not easy. Considering the significant roles of textbooks in the teaching and learning of EFL, it is crucial to decide appropriate contents that are in line with the current curriculum applied ${ }^{8}$ because the learning activities presented in textbooks reflect the belief and value of curriculum substances. ${ }^{9}$ Although there are many textbooks available in the market, Tomlinson argues high-quality EFL textbooks should be relevant with principles of curriculum applied in a

\footnotetext{
${ }^{6}$ Alan Cunningsworth, Choosing Your Coursebook (Oxford: Heineman, 1995), 10.

7 Ivan Ivić, "Printed and Digital Media: Printed and Digital Textbooks," Center for Educational Policy Studies Journal 9, no. 3 (2019): 25-49, https://doi.org/10.26529/cepsj.694.

8 Cunningsworth, Choosing Your Coursebook; Reza Gholami, Nooreen Noordin, and Shameem Rafik-Galea, "A Thorough Scrutiny of ELT Textbook Evaluations: A Review Inquiry," International Journal of Education and Literacy Studies 5, no. 3 (July $\quad 31, \quad 2017)$ : 82-91, https://doi.org/10.7575/aiac.ijels.v.5n.3p.82.

${ }^{9}$ Hossein Hashem Neghad, "Reflection of Learning Theories in Iranian ELT Textbooks," Advances in Language and Literary Studies 5, no. 2 (2014): 115-19, https://doi.org/10.7575/aiac.alls.v.5n.2p.115.
} 
particular level of education. ${ }^{10}$ In this case, textbook evaluation is needed to make a better teaching and learning process for teachers and students, as textbook evaluation ensures the materials provided are interrelated with the required characteristics, such as postulated in the curriculum. $^{11}$

One of the curriculum approaches is Outcome-Based Education (henceforth, OBE), which emphasized students' learning outcomes accomplishment and student-centered learning. Khannaa \& Mehrotra mention that since this OBE curriculum is new to the teaching of EFL at university level, several activities including textbook evaluation should be applied to know whether the available materials are still relevant or not with $\mathrm{OBE}$ principles. $^{12}$

\footnotetext{
10 Ataollah Maleki, Fariba Mollaee, and Robab Khosravi, "A Content Evaluation of Iranian PreUniversity ELT Textbook," Theory and Practice in Language Studies 4, no. 5 (2014): 995-1000, https://doi.org/10.4304/tpls.4.5.995-1000; Brian Tomlinson, Developing Materials for Language Teaching (London: A\&C Black, 2003); Brian Tomlinson, English Language Learning Materials: A Critical Review (London: Continuum, 2008); Brian Tomlinson, "What Do Teachers Think about English Coursebooks?," Modern English Teacher 19, no. 4 (2010): 5-9.

${ }^{11}$ Carl-Christian Fey and Eva Matthes, "Textbook Quality Criteria and Evaluation," in The Palgrave Handbook of Textbook Studies, ed. Eckhardt Fuchs and Annekatrin Bock (New York: Palgrave Macmillan US, 2018), 157-67, https://doi.org/10.1057/978-1-137-53142-1_11.

12 Richa Khanna and Divya Mehrotra, "The Roadmap for Quality Improvement from Traditional through Competency Based (CBE) Towards Outcome Based Education (OBE) in Destistry," Journal of Oral Biology and Craniofacial Research 9, no. 2 (2019): 139-42, https://doi.org/10.1016/j.jobcr.2019.02.004.
}

To fulfill OBE principles, EFL textbook evaluation should be done to all aspects of the textbooks. Appropriate textbooks contents with OBE principles should be investigated to prove that the EFL learning objectives have been suitable. To construct relevant learning outcomes with OBE principles, EFL textbook content usefulness should be investigated. ${ }^{13}$ Besides that, Mertens emphasizes that contextual learning tasks as well as activities should be analyzed too because one of OBE principles, namely real life experience should be exposed in the classroom. ${ }^{14}$ Through this evaluation, desirable EFL textbooks' aspects, especially its components ${ }^{15}$ are eligible to provide $\mathrm{OBE}$ principle, i.e., independent learning. Further, textbook evaluation at three stages of a course implementation helps foresee, assess, and review the overall quality of textbooks, which are used as teaching and learning tools for students' English language development ${ }^{16}$ under the basis of OBE principle: English language lifelong learning.

A number of previous studies have been carried out in relation to EFL textbooks. Firstly, there was a study conducted by Maleki entitled $A$ Content

\footnotetext{
13 Maleki, Mollaee, and Khosravi, "A Content Evaluation of Iranian Pre-University ELT Textbook," 995-1000.

${ }^{14}$ Donna M. Mertens, Research and Evaluation in Education and Psychology: Integrating Diversity With Quantitative, Qualitative, and Mixed Methods (London: SAGE Publications, 2014), 102.

${ }^{15}$ Cunningsworth, Choosing Your Coursebook. 15.

${ }^{16}$ Niwat Wuttisrisiriporn and Siriluck Usaha, "The Development of a Localized ELT Textbook Evaluation Checklist: A Case Study from Thailand," Thaitesol Journal 32, no. 2 (2019): 46-64.
} 
Evaluation of Iranian Pre-University English Language Teaching (ELT) Textbook that mainly discussed the importance of evaluation so as to ensure ELT textbooks can effectively facilitate the attainment of the teaching objectives, and at the same time, be economically viable to teachers and students. ${ }^{17}$ It revealed a significant result as unforeseen results that the participants were not mostly satisfied with this English textbook because the calculated mean for all the questions was below 3, which means adequate. The findings revealed that there are some existed demerits for this English textbook that need to be revised.

Another study that is similar to the topic is conducted by Widodo that analyzed a textbook using the three phases of the textbook analysis, concerning the three main features of the textbook: (1) goal and organization, (2) contents-inputs, models, and exercises, and (3) the suitability of the textbook viewed from aims, beliefs about writing, the roles of the teacher, the role of the students, and the roles of the textbook as a whole. ${ }^{18}$ According to him, textbook becomes a priority when it comes to teaching English language.

Mukundan and Nimehchisalem also researched evaluating textbooks. ${ }^{19}$ The

\footnotetext{
${ }^{17}$ Ataollah Maleki, "A Content Evaluation of Iranian Pre-University ELT Textbook” 4, no. 5 (2014): 9951000, https://doi.org/10.4304/tpls.4.5.995-1000.

18 Handoyo Puji Widodo, "Textbook Analysis on College Academic Writing," TEFLIN Journal 18, no. 2 (2007): $109-22$ https://doi.org/10.15639/teflinjournal.v18i2/109-122. 19 Jayakaran Mukundan and Vahid Nimehchisalem, "Evaluative Criteria of an English Language Textbook Evaluation Checklist," Journal of
}

researcher used a valid and reliable checklist to evaluate the Malaysian English language teaching textbook. Then the result showed that Year 1 to Year 6 teachers reported that the current textbooks are 'highly useful' to the students. Meanwhile, Form 1 to Form 5 teachers contended that the school books are only 'moderately useful.'

In another article, Asiyaban evaluate the Intermediate ILI (Iran Language Institute) English Series by running the questionnaire. The results show that although the series favor some strong points, most of the sections of the textbooks suffer a few pitfalls. ${ }^{20}$ Moreover, the overall evaluation of the series manifests the average level of satisfaction in every component on the part of the teachers. Also, the ideas of male and female instructors were different in the "Conclusion," "Subject and Content," and "Language Type" categories.

Accordingly, the previous studies focus on various theories based on textbook evaluation experts who have not been related to OBE principles. In fact, these OBE principles are commonly used as the basis of nationwide curriculum improvement for tertiary levels of education. Therefore, as a part of curriculum improvement, textbook evaluation based on OBE principles is inevitable. Thus, to accommodate this, the

\footnotetext{
Language Teaching and Research 3, no. 6 (2012): 1128-34, https://doi.org/10.4304/jttr.3.6.1128-1134.

20 Amir Reza Asiyaban, "Scrutinizing the Appropriateness of the Intermediate ILI English Series in the EFL Context of Iran" 4, no. 6 (2014): 1257-65, https://doi.org/10.4304/tpls.4.6.12571265.
} 
study on textbook analysis which includes OBE principles, is worth researching.

This study addresses the following research questions as three main concerns. The first concern is about the module content whether it is related to all the aspects of OBE and the learners' real life or not, and the second concern is the language items used in the module were communicative and authentic enough or not, and the last concern is the illustrations presented in the module were interesting and varied enough or not.

\section{B. Method}

This study employed a descriptive quantitative method with a checklist as the main instrument. The checklist was developed based on theories of Cunningsworth, ${ }^{21}$ Ur, ${ }^{22}$ Reiss, ${ }^{23}$ and Pedoman Pendidikan Fakultas (for ELT Program). ${ }^{24}$ The checklist consisted of three dimensions and eight subdimensions. The dimensions were elaborated on the main points of the module, they are contents, language items, and illustrations. The subdimensions of module content were material suitability with the curriculum, material accuracy, and supports for the materials. Meanwhile, the sub-dimensions of module language items were

\footnotetext{
${ }^{21}$ Cunningsworth, Choosing Your Coursebook.

22 Penny Ur, A Course in Language Teaching (Cambridge: Cambridge University Press, 2008), 184

23 Jodi Reiss, Teaching Content to English Language Learners (New York: Longman, 2005), 64.

${ }^{24}$ Pedoman Pendidikan Fakultas (for ELT Program) (Malang: Fakultas IImu Budaya, Universitas Brawijaya, 2017), 99.
}

compatible with students' level and communicativeness. Lastly, the subdimensions of module illustrations consist of presentation technique, presentation of learning, and completeness of presentation. The instrument validation was done by two lecturers who are experts and practitioners in ELT. Minor revisions on the checklist related to sub-dimensions descriptions and some language structures were discussed and revised.

After the textbook evaluation results based on OBE principles have done, the researchers also asked another ELT lecturer to check the results. Discussions were undergone to reassure appropriate parts from the Extensive Reading module that became proofs for each subdimension on the checklist. These were done to guarantee the trustworthiness of results of the textbook evaluation.

Extensive Reading Module for an ELT program from a reputable University in East Java, Indonesia, became the main data source. The module consisted of three chapters that mainly discussed reading popular articles, scientific articles, and abridged novels. This module was used in the program from 2015 to 2018 when the curriculum was solely based on national qualification framework. The data were collected by checking each chapter materials' relevancies to the checklist as the major research instrument. Appropriate materials based on the checklist were ticked and totaled. After that, those totals were put in percentages to indicate relevancies to each dimension in the instrument, which showed whether the textbook applied OBE principles or not. 


\section{Results}

The research findings from the textbook evaluation comprise module contents, module language items, and module illustrations. Further elaborations are explained as follows.

\section{Module Contents}

There were three sub-dimensions that described the module contents in evaluating an Extensive Reading module, namely material suitability, material accuracy, and learning support materials. Material suitability of the module was examined by matching the curriculum implemented, which was based on OBE principles, main characteristics of the ELT program, and ELT graduate profiles. Meanwhile, materials accuracy showed that the module had provided learning objectives that indicate students' ability to achieve each chapter. Accordingly, learning support materials measured relevant topics, class activities, and assessment which execute teaching and learning indicators.

\section{a. Material Suitability with the Curriculum}

The module should indicate relevancy with the implementation of the current curriculum, accuracy for learning outcomes, and indicators should be stated clearly and feasibly. After the textbook evaluation, the results yielded that the materials are not suitable yet with the ELT program characteristics or learning outcomes/ indicators. It showed that the module has not provided learning objectives that need to be in line with intercultural communication competence,
Information and Communication Technology (ICT)-based integration in teaching and learning, and inclusive education, notably in ELT. Besides, some student-centered learning methods and critical thinking approach should be emphasized. Thus, several learning outcomes set have not met the graduate profiles for the new curriculum postulation. Several examples can indicate these situations, like systemic pre-reading activities appeared to be monotonous lack of reading materials that show variety in cultural, ICT-based integration, or inclusive education aspects. Besides that, learning objectives need to be focused more on students' critical thinking to compare or contrast and develop reading logs and reviews in relation to cultural values, ICT-based instructional materials and media, and inclusive education principles. The student-centered learning method has been initiated in the Extensive Reading course classroom activities, yet it needs to be formulated explicitly in the learning outcomes.

As portrayed in the Table 1 below, module contents are ranged among 1-4, mostly, the score which was gotten by each dimension was either 1 or 2 . In detail, the curriculum suitability only scored 1, learning outcomes only scored 1 , and learning objectives only scored 2 . Meanwhile, material completeness only scored 1, and the extent of the materials, especially which relates to exposure scored 2, retention scored 2, and production scored 1 respectively. Therefore, the sub-dimension mentioned about material suitability indicated that 
many things should be revised so that module contents will fulfill the new curriculum suitability, reflecting $\mathrm{OBE}$ principles suitable for the ELT program.

Table 1.

Material Suitability with The Curriculum

\begin{tabular}{llll}
\hline Dimension & Sub dimension & Item & Score \\
\hline 1. Module Contents & Material Suitability with The & 1. Curriculum Suitability & \\
& Curriculum & 1.1 Learning Outcomes & 1 \\
& & 1.2. Learning indicators & 2 \\
& 2. Material Completeness & 1 \\
& 3. Extent of Materials & 2 \\
& 3.1. Exposure & 2 \\
\hline
\end{tabular}

Source: Pedoman Pendidikan Fakultas (for ELT Program), 99.

\section{b. Material Accuracy}

Material accuracy deals with OBE and ELT program characteristics. The module should include inclusive education, ICT-based integration, and intercultural competence communication materials. In this module, students are provided with instructional materials which show some reading texts models, especially about popular articles, scientific articles, and abridge novels. This module consisted of three main chapters related to those different reading genres for the whole one-semester period (14 meetings). Each chapter began with reading activities related to the reading passage based on the various genre, followed by comprehension questions and closed by guiding steps to make written review on a piece of paper. The review consisted of summary and personal comments.
However, further explanations and examples were needed to show the social function, generic structure, and linguistic features of every reading text with different genres in the module. These activities should have been followed by several student-centered activities which accommodate evaluating and creating the process of learning.

In relation to a social function, the module lacked information to guide students to identify the purposes of the reading texts, which led to difficulties in evaluating the reading texts provided as the examples in the module. Without building knowledge to analyze the social functions of the texts, students could have problems when they are assigned to write a review or reading log, especially in developing the summary part. The module has not provided a clear picture of the generic structure for the reading texts 
discussed. Either popular articles, scientific articles, or simplified novels were presented as reading passages without considering the organization of each text genre. Identifying the reading texts structure actually aided students to determine, support, and criticize the content of particular texts, which actually help them compose personal comments that are needed in the review or reading logs. Linguistics features discussion was not found in the module. This could be trivial, but this could help students prevent confusion in understanding the meaning or contents conveyed through the reading texts.

Moreover, several reading texts that became the module models have not fulfilled some required topics about inclusive education, ICT-based integration, and intercultural competence communication. In other words, the topics provided in the module neither met the OBE principles nor the new curriculum concepts, as popular articles, scientific articles and abridge novels which presented in the module were miscellaneous.

As depicted in Table 2, in relation to material accuracy, the dimension about module contents was assed in range 1-4, mostly scores obtained by each item of subdimension material accuracy were 1 or 2. In detail, Table 2 has already shown that social function scored 1, text structure scored 1, and linguistic features scored 2. So, the material accuracy of this module should be revised so that the module contents should relate to the discussion on each reading text genre's social function, text structure, and linguistic features with learning activities that encourage students' skills in the 21 st century.

Table 2.

Material Accuracy

\begin{tabular}{llll}
\hline Dimension & Sub dimension & Item & Score \\
\hline 1. Module Contents & Material Accuracy & 1. Social Function & 1 \\
& & 2. Text Structure & 1 \\
& & 3. Linguistic Feature & 2 \\
\hline
\end{tabular}

Source: Cunningsworth, Choosing Your Coursebook, 15; Ur, A Course in Language Teaching, 184; Reiss, Teaching Content to English Language Learners, 64; and Pedoman Pendidikan Fakultas (for ELT program), 99.

\section{c. Learning Support Material}

Learning support material deals with topics and tasks which are offered in the module. Interesting and various topics and tasks are more preferable to build meaningful learning as it is suggested by OBE principles. In this module, integrated teaching and learning activities with ICT were not significantly encouraged other than downloading individual reading texts from websites. Further ICT-based instructional media, materials, or assessments are needed. Each module chapter is highly suggested to provide 
sources for further study as the enrichment materials. It would be better if further information to enhance students' skills and achievement can be accessed online. The use of barcodes to access the materials can become another option so that the printed module can be more concise.

Even the follow-up activities for students lacked of 21 st-century skills. The module was urgent to be improved so that critical thinking, problem-solving, communication, and collaboration skills are reflected in the module and further to be implemented through classroom teaching and learning activities.

When OBE principles are employed, students' critical thinking can be stimulated by providing scaffolding in the module so that students can respond to Extensive Reading materials critically, and in the future, they can use them for humanity. Skilled in solving problems should be reflected in the module, giving students the opportunity to finish the assignments in more various and more interesting media to publish their work. By giving students many options to solve tasks in the Extensive Reading class, students are practicing to overcome problems during learning activities, and further, they get used to face and even solve bigger problems in life. Besides, communication skills refer to identifying, accessing, utilizing, and optimizing communication tools and techniques to receive and convey information to other parties. In this Extensive Reading module, students need to be guided with materials and learning activities that train students to work together when they are accomplishing assignments or sharing knowledge and values after reading. This is in line with the OBE principle that skilled collaboration can be achieved by providing students a chance to collaborate with others to increase synergy in learning.

As depicted in table 3, module contents sub-dimensions showed scale of $1-4$, and mostly the sub-dimension items scored 1. In detail, learning support material source and competencies knowledge with ICT-based learning only scored 1 respectively. Therefore, the module needs to be revised to fulfill the appropriate learning support materials for the module contents.

Table 3.

Learning Support Material

\begin{tabular}{llll}
\hline Dimension & Sub dimension & Item & Score \\
\hline 1. Module Contents & Learning Support Material & $\begin{array}{l}\text { 1. Source } \\
\end{array}$ & $\begin{array}{l}\text { 2. Competencies Knowledge } \\
\text { and ICT-Based Learning }\end{array}$ \\
\hline
\end{tabular}

Source: Cunningsworth, Choosing Your Coursebook, 15; Ur, A Course in Language Teaching, 184; Reiss, Teaching Content to English Language Learners, 64; and Pedoman Pendidikan Fakultas (for ELT program), 99. 


\section{Module Language Items}

The Extensive Reading module language items can be measured through two sub-dimensions, i.e., compatibility with students' level and communicativeness. Further results and discussion related to those subdimensions are explained as follows.

\section{a. Appropriateness with learners}

Two items, namely students' cognitive and students' socio and emotional levels are main factors which affect the module appropriateness with learners. The language used in the explanation and instruction was too direct, leading to further questions or explanation from lecturers. In other words, appropriateness with learners deals with its language forms, including language use, plenty of authentic languages, clear instruction, and the varieties of English. However, in this module, language use, particularly which was used to give instructions or directions, needed more elaborations with examples for each chapter related to post-reading assignments.

Besides, some varieties of English were not exposed yet because the module did not present sufficient exposure to the various cultural knowledge. The instructions mostly focused on the final products which needed to accomplish by students; thus, the module needs to be revised to provide students with leading questions to make them experience learning process before writing the review or reading logs. These are scaffoldings that guide students' learning strategies. Therefore, more explanations or instructions suitable for students' cognitive and socio-emotional levels are urgently needed.

As shown in table 4, module appropriateness with learners are assessed among range 1-4, mostly scores in this dimension was 1. In detail, appropriateness with students' cognitive level only scored 1, and students' socioemotional also scored 1. These data reveals that the module materials were not appropriate for learners. The improvement, especially for the explanation and instruction in the module should be in accordance with the students' cognitive development level. The level of difficulty and familiarity of the language should be explicitly facilitated to accommodate students' socio-emotional levels.

Table 4.

Compatibility with Students' Level

\begin{tabular}{llll}
\hline Dimension & Sub dimension & Item & Score \\
\hline $\begin{array}{l}\text { 2. Module Language } \\
\text { Items }\end{array}$ & $\begin{array}{l}\text { Appropriateness with } \\
\text { learners }\end{array}$ & 1. Students' Cognitive & 1 \\
& & 2. Students' Socio-Emotional & 1 \\
\hline
\end{tabular}

Source: Cunningsworth, Choosing Your Coursebook, 15; Ur, A Course in Language Teaching, 184; Reiss, Teaching Content to English Language Learners, 64; and Pedoman Pendidikan Fakultas (for ELT program), 99. 


\section{b. Communicativeness}

Communicativeness of the Extensive Reading module can be indicated by clear and understandable messages, including explanations and directions use and language appropriateness with English grammatical rules. Module communicativeness is emphasized by sequential and unity of materials provided.

In this module, the students seem get difficulties in taking benefits after learning each chapter if it is related to OBE principles. The materials presented did not cover intercultural communication, inclusive education, and ICT-based integration topics, which become the main learning outcomes in the ELT curriculum. The task instructions needed some improvement to lead the student-centered and collaborative learning. However, this module has been already employed proper English, as there was no grammatical error found in explanations and instructions. The module was presented in sequential order, from explanation, example, and exercises. Nevertheless, warming up activities which activate students' background knowledge are needed, besides various assessment methods, like self-assessment or peer assessment should be added to implement collaboration skill among students.

In the table 5, language items of this module showed in range 1-4, and most scores that this dimension got was 3 . In detail, languages' rules, coherent meaning, and sequential and unity were scored 3. Nonetheless, learning messages was only scored 1 which means that the module needs to be improved on understandable and clear messages which can be reached by providing appropriate learning objectives, materials, assignment, and assessment that relate to the new curriculum.

Table 5.

Communicativeness

\begin{tabular}{llll}
\hline Dimension & Sub dimension & Item & Score \\
\hline 2. Module Language Items & Communicativeness & 1. Learning' Messages & 1 \\
& & 2. Languages' Rules & 3 \\
& & 3. Sequential and unity & 3 \\
\hline
\end{tabular}

Source: Cunningsworth, Choosing Your Coursebook, 15; Ur, A Course in Language Teaching, 184; Reiss, Teaching Content to English Language Learners, 64; and Pedoman Pendidikan Fakultas (for ELT program), 99.
3. Module Presentation Expediency Presentation expediency comprises three sub-dimensions, namely
presentation, and presentation completeness. They are described as follows. presentation technique, learning 


\section{a. Presentation Technique}

The presentation technique of the extensive reading module should consist of materials and tasks are presented in the form of texts, communicative action illustration, and symbol by following the rule of opening, content, closing (systematic), and materials and tasks are presented in the form of texts, communicative action, illustration, and symbol equally in each chapter (interchapter balance).

In this module, the systematic part has not been achieved because the module just presented explanation about the topics and directions to do tasks which were not completed with any communicative action illustrations. No symbols were found to mark opening, content, or closing. This somehow created boredom for students since the module was presented in too many written texts. Some audio or video materials should have been provided in the module to improve students' competence in comprehending various texts for
Extensive Reading. Symbols were needed to improve the module's presentation so that students will be easier to label every opening, content, and closing part of the module. Even though the module lacked systematic part, it has shown better interchapter balance. This was proven that every chapter had opening, content, and closing parts. However, to improve students' English skills, the contents in each chapter should accommodate reading, speaking, listening, and writing skills by providing various models of the texts as reading passages and tasks as reviews.

Table 6 shows that 1-4 ranges were used to measure the module presentation technique. There were two items to indicate this sub-dimension. The systematic item only scored 1 , and the other one was inter-chapter balance only scored 2. These scores mean that the revision was highly suggested to do for the systematic and inter-chapter balance items to improve the Extensive Reading presentation technique.

Table 6.

Presentation Technique

\begin{tabular}{|c|c|c|c|}
\hline Dimension & Sub dimension & Item & Score \\
\hline $\begin{array}{l}\text { 3. Module } \\
\text { Presentation } \\
\text { Expediency }\end{array}$ & Presentation Technique & $\begin{array}{l}\text { 1. Systematic } \\
\text { 2. Inter-chapter balance }\end{array}$ & $\begin{array}{l}1 \\
2\end{array}$ \\
\hline
\end{tabular}

Source: Pedoman Pendidikan Fakultas (for ELT program), 99.

\section{b. Learning Presentation}

Learning presentation deals with class activities that use instructional materials from the module. This module is supposed to be student-centered. In fact, the module still lacked materials and tasks which encouraged occurrence of interaction in English inter-learner, 
between teacher and learners, and between learners and environment. The functions offered in the modules were focusing on the final product, i.e., composing reading logs and reviews in the written forms, which were typed and printed after individual reading tasks. Actually, student-centered learning can be done by encouraging students to experience a process writing technique when composing a review.

Learning presentations also lacked activities that develop students' initiative, creativity, and critical thinking. The module has not provided materials and tasks presentation encourage the learners to do an oral and written communicative activity based on their initiatives creatively and critically. To promote students' initiative, the module should not only give students a single form of writing reviews or reading logs. The variations like writing on a blog or creating short audios or videos can also become options to reviews the reading materials. These also help students to stimulate their creativity when presenting their reading task reviews.

However, further activities which relate to foster critical thinking in developing reviews need to improve because the task provided in the module just commands students to write reviews. To stimulate students' critical thinking in composing reviews, several classroom activities should be added, like how to summarize with sufficient coverage of the topic, how to make critical and analytical approach, and how to make personal comments from the individual interpretation of the literature offered. One of activities that can be offered is providing scaffoldings to guide students' activities in fostering their critical thinking. This series of activities should become habitual actions for students so that later, students get accustomed to think critically about anything, for instance, from something that they read. In other words, this is actually practiced to encourage students to be responsible for their learning process, so they will be selfdirected learners in the future.

The module was prepared to have learning assessments, meaning that lectures were the ones who were responsible for giving students feedback and scores. This module has not offered opportunities for students to do selfassessment nor peer assessment (assessment of learning). In fact, to do an appropriate assessment, a course should consider assessment for learning, assessment of learning, and assessment as learning.

As seen in table 7, range of module learning presentation are 1-4, and there were four items to indicate this subdimension, namely student-centered, students' initiative and creativity, independence learning, and evaluation. The findings yielded that all items scored 1 each, so that the module learning presentation needs to be revised and improved. 
Table 7.

Learning Presentation

\begin{tabular}{llll}
\hline Dimension & Sub dimension & Item & Score \\
\hline 3. Module Presentation & Learning Presentation & 1. Student-Centered & 1 \\
Expediency & & 2. Students' Initiative and Creativity & 1 \\
& & 3. Independence Learning & 1 \\
& 4. Evaluation & 1 \\
\hline
\end{tabular}

Source: Reiss, Teaching Content to English Language Learners, 64.

\section{c. Presentation Completeness}

Completeness of presentation deals with technical supports of a module like availability of preface and table of content in the beginning part of the module, availability of learning objectives and indicators, learning duties, and references in the content of the module, and availability of glossaries, bibliography, and index in the last part of the module. In the beginning part of the module, there were a preface and table of contents right after the module cover, and then the contents did not provide sufficient structural exercises, autonomous activities, illustrations. Moreover, in the last part of the module, we could not find any glossaries and index.

In Table 8, this module presentation completeness showed in range 1-4. There were three items that explain this subdimension. The opening part of the module had the best score among the others, for it scored 3; meanwhile, the content and the closing parts of the module only scored one respectively. So, it is important to pay more attention to these presentations completeness of the module when it comes to the revision.

Table 8.

Presentation Completeness

\begin{tabular}{llll}
\hline Dimension & Sub dimension & Item & Score \\
\hline 3. Module & Presentation Completeness & 1. Opening & 3 \\
Presentation & & 2. Content & 1 \\
Expediency & 3. Closing & 1 \\
\hline
\end{tabular}

Source: Reiss, Teaching Content to English Language Learners, 64.

This textbook evaluation study was based on OBE principles. Khannaa \& Mehrotra's stated that OBE method is needs-driven, results-driven, design-down, defines outcomes and levels of outcomes, moves the focus from teaching to learning, and offers a framework with holistic results. ${ }^{25}$

25 Khanna and Mehrotra, "The Roadmap for Quality Improvement from Traditional through Competency Based (CBE) Towards Outcome Based Education (OBE) in Destistry," 139-42. 
Therefore, learning goals are means to achieve the goals/objectives of the entire plans, and their purpose is not just to achieve the learning goals themselves. It follows the design downward and delivery upward approach, starting from the endpoint (from the expected result of the entire education plan) and inverting the curriculum, which means that the curriculum is inverted. When planning the teaching/pedagogy, the teacher will teach the students what they need to learn to prove these established results. This means, the Extensive Reading module should follow these principles which actually have been reflected through the new curriculum made by this ELT program. Therefore, the module needs to be examined whether or not it is still relevant to the new curriculum and learning outcomes.

The results from the module evaluations can be summarized as follow in Table 9.

Table 9.

Overall Number of Extensive Reading Module

\begin{tabular}{llll}
\hline Sub Dimension & $\begin{array}{l}\text { Module } \\
\text { Contents }\end{array}$ & $\begin{array}{l}\text { Module } \\
\text { Language } \\
\text { Items }\end{array}$ & $\begin{array}{l}\text { Presentation } \\
\text { Expediency }\end{array}$ \\
\hline Material Suitability with The Curriculum & 10 & & \\
Material Accuracy & 4 & 2 & \\
Learning Support Material & 2 & 2 & 3 \\
Appropriateness with learners & & 10 & 4 \\
Communicativeness & & 5 \\
Presentation Technique & & & 5 \\
Learning Presentation & & & \\
Presentation Completeness & & & \\
\hline
\end{tabular}

This data shows that the Extensive Reading Module score in terms of contents was 16 , language items were 12 , and presentation expediency was 12 . The total percentage of those three criteria dimensions was $33.33 \%, 50 \%$, and $36.11 \%$.

The findings yielded that the module content dimension did not accommodate the OBE principles. First, the module has shown a lack of characteristics postulated in the new curriculum for this ELT program because it did not include sufficient intercultural communicative competence; moreover, it lacked inclusive education and ICT-based integration materials or tasks.

Thus, the content of this module needs to be improved for the suitability of the Extensive Reading module by following the OBE principles. Cunningsworth also stated that the importance of material really matters in language teaching. The material needs to 
compile all the students' activities that are reliable with their real-life in class or at home. ${ }^{26}$ This is a clue that the module should have the best activities to facilitate students' learning process. Accordingly, the overall module contents dimension results were $33.33 \%$, which means that it does not meet the OBE qualification. The score is categorized as very poor. This is a fact that the module content needs many improvements soon.

Besides that, concerning language items dimension, the module showed that actually there are no ungrammatical sentences found. However, based on OBE principle, the module should provide more communicative language for the learners. As Zou agreed, communicative activities are possible to improve students' communication strategies to express and explore their ideas with their friends. This brings emphasis that language is a serious component to level up the learning process. $^{27}$

The module's language items should be improved, for the results of the overall module language items dimension is $50 \%$, which indicates only half parts of the module which meet the qualification. It was still in the poor qualification category, so that it needs a revisit immediately. Eventually, the module presentation expediency also indicated that the module needs to be revised soon because the module still lacked interesting illustrations,

\footnotetext{
${ }^{26}$ Cunningsworth, Choosing Your Coursebook.

27 Bin Zou, Hui Li, and Jiaying $\mathrm{Li}$, "Exploring a Curriculum App and a Social Communication App for EFL Learning," Computer Assisted Language Learning 31, no. 7 (2018): 694-713, https://doi.org/10.1080/09588221.2018.1438474.
}

meaningful activities, and important technical parts of a module.

Mulyasa proved that create fun learning will build a strong and sincere relationship between teachers and students. ${ }^{28}$ Blume also said that attractive and meaningful learning tasks should be connected with fruitful materials. ${ }^{29}$ Interactive illustrations and layout can help the module to present a better presentation technique of a module. More scaffoldings are needed to guide students with materials which lead to the studentcentered learning situation, develop initiative, creative, and critical thinkingbased instructions, foster learning autonomy, and develop the ability of selfreflection or evaluation.

The overall module presentation expediency results are $36.11 \%$, which is categorized as very poor, as mostly it does not apply any OBE principles. The results of this research were actually similar to a study which was once conducted by Yan Fei, which stated that revision of tasks and materials of a course book could be done if the available instructional materials or media were not suitable with the current conditions, one of them was a new curriculum. ${ }^{30}$

${ }^{28}$ E. Mulyasa, Pengembangan dan Implementasi Kurikulum 2013 (Bandung: PT. Remaja Rosdakarya, 2013), 6.

${ }^{29}$ Carolyn Blume, "Games People (Don't) Play: An Analysis of Pre-Service EFL Teachers' Behaviors and Beliefs Regarding Digital Game-Based Language Learning," Computer Assisted Language Learning 33 (2020): 109-32, https://doi.org/10.1080/09588221.2018.1552599.

${ }^{30} \mathrm{Su}$ Yan-Fei, "An Evaluation of Extensive Reading Course Book-Contemporary College English: Companion Reader," US-China Foreign Language 
By revisiting the instructional materials and media, students' capacity and skills can be enhanced to reach the learning outcomes, and the new curriculum implementation was successful. Eventually, based on the evaluation results above, further revision is needed to improve the Extensive Reading module to be in line with OBE principles embedded into the aforementioned ELT program's new curriculum.

\section{Conclusion}

This study revealed some weaknesses of Extensive Reading learning materials and media in the form of module evaluation. This study emphasizes the importance of conducting a textbook evaluation, especially based on the updated curriculum, Outcome-Based Education, which stresses the outcomes and the assessment. Then the result of such an evaluation can give a different insight to identify more about the weakness and the deficiency that can lead into the revision. These current research findings becomes one of the foundations that can be used to revisit the module; although it is only one of the initial research done before revising the module, more information is obtained from a focusgroup discussion the head of the aforementioned ELT program as well as previous lectures and a survey of earlier students. Therefore, further studies can be undergone through quantitative or qualitative methods.

\footnotetext{
14, no. $10 \quad$ (2016): $717-22$,
} https://doi.org/10.17265/1539-8080/2016.10.007.

\section{Acknowledgment}

This study was funded by the Faculty of Cultural Science Universitas Brawijaya, Indonesia, through a Penelitian $D P P / S P P$ Grant (0818.1/UN10.F12/PN/2020).

\section{References}

Adi, Hayati Wasistyo, and Puji Astuti. "Content Analysis of Student Book When English Rings a Bell (Revised Edition) for Grade VIII of Junior High School." ELT Forum: Journal of English Language Teaching 8, no. 1 (2019): 49-59. https://doi.org/10.15294/elt.v8i1.261 38.

Asiyaban, Amir Reza. "Scrutinizing the Appropriateness of the Intermediate ILI English Series in the EFL Context of Iran" 4, no. 6 (2014): 1257-65.

https://doi.org/10.4304/tpls.4.6.1257 -1265 .

Blume, Carolyn. “Games People (Don't) Play: An Analysis of Pre-Service EFL Teachers' Behaviors and Beliefs Regarding Digital GameBased Language Learning." Computer Assisted Language Learning 33 (2020): 109-32. https://doi.org/10.1080/09588221.20 18.1552599 .

Cortazzi, Martin, and Lixian Jin. "Cultural Mirrors: Materials and Methods in the EFL Classroom." In Culture in Second Language Teaching and Learning, edited by Eli Hinkel. Cambridge: Cambridge University Press, 1999.

Cunningsworth, Alan. Choosing Your Coursebook. Oxford: Heineman, 1995.

Fey, Carl-Christian, and Eva Matthes. "Textbook Quality Criteria and Evaluation." In The Palgrave Handbook of Textbook Studies, 
edited by Eckhardt Fuchs and Annekatrin Bock, 157-67. New York: Palgrave Macmillan US, 2018. https://doi.org/10.1057/978-1-13753142-1_11.

Gholami, Reza, Nooreen Noordin, and Shameem Rafik-Galea. "A Thorough Scrutiny of ELT Textbook Evaluations: A Review Inquiry." International Journal of Education and Literacy Studies 5, no. 3 (2017): 82-91.

https://doi.org/10.7575/aiac.ijels.v.5n .3p.82.

Hashem Neghad, Hossein. "Reflection of Learning Theories in Iranian ELT Textbooks." Advances in Language and Literary Studies 5, no. 2 (2014): 115-19.

https://doi.org/10.7575/aiac.alls.v.5n .2p.115.

Ivić, Ivan. "Printed and Digital Media: Printed and Digital Textbooks." Center for Educational Policy Studies Journal 9, no. 3 (2019): 2549.

https://doi.org/10.26529/cepsj.694.

Khanna, Richa, and Divya Mehrotra. "The Roadmap for Quality Improvement from Traditional through Competency Based (CBE) Towards Outcome Based Education (OBE) in Dentistry." Journal of Oral Biology and Craniofacial Research 9, no. 2 (2019): 139-42. https://doi.org/10.1016/j.jobcr.2019.0 2.004.

Lee, C.Y., and Hsien-Chin Liou. "A Study of Using Web Concordancing for English Vocabulary Learning in a Taiwanese High School Context." English Teaching \& Learning 27 (2003): 35-56.

Maleki, Ataollah, Fariba Mollaee, and Robab Khosravi. "A Content Evaluation of Iranian Pre-University ELT Textbook." Theory and Practice in Language Studies 4, no. 5 (2014): 995-1000.

https://doi.org/10.4304/tpls.4.5.9951000.
Mertens, Donna M. Research and Evaluation in Education and Psychology: Integrating Diversity With Quantitative, Qualitative, and Mixed Methods. London: SAGE Publications, 2014.

Mukundan, Jayakaran, and Vahid Nimehchisalem. "Evaluative Criteria of an English Language Textbook Evaluation Checklist." Journal of Language Teaching and Research 3 , no. 6 (2012): 1128-34. https://doi.org/10.4304/jltr.3.6.11281134.

Mulyasa, E. Pengembangan dan Implementasi Kurikulum 2013. Bandung: PT. Remaja Rosdakarya, 2013.

Pedoman Pendidikan Fakultas (for ELT Program). Malang: Fakultas IImu Budaya, Universitas Brawijaya, 2017.

Reiss, Jodi. Teaching Content to English Language Learners. New York: Longman, 2005.

Richards, Jack C. Curriculum Development in Language Teaching. Cambridge: Cambridge University Press, 2001.

Sheldon, Lee. "Evaluating ELT Textbooks and Materials." ELT Journal 42, no. 4 (1988): 237-46.

Sun, Ye, and Thi Ngoc Yen Dang. "Vocabulary in High School EFL Textbooks: Texts and Learner Knowledge." System 93 (2020): 102-279.

https://doi.org/10.1016/j.system.202 0.102279 .

Tomlinson, Brian. Developing Materials for Language Teaching. London: A\&C Black, 2003.

Tomlinson, Brian. English Language Learning Materials: $A$ Critical Review. London: Continuum, 2008.

Tomlinson, Brian. "What Do Teachers Think about English Coursebooks?" Modern English Teacher 19, no. 4 (2010): 5-9. 
Ur, Penny. A Course in Language Teaching. Cambridge: Cambridge University Press, 2008.

Widodo, Handoyo Puji. "Textbook Analysis on College Academic Writing." TEFLIN Journal 18, no. 2 (2007): 109-22. https://doi.org/10.15639/teflinjournal. v18i2/109-122.

Wuttisrisiriporn, Niwat, and Siriluck Usaha. "The Development of a Localized ELT Textbook Evaluation Checklist: A Case Study from Thailand." Thaitesol Journal 32, no. 2 (2019): 46-64.
Yan-Fei, Su. "An Evaluation of Extensive Reading Course BookContemporary College English: Companion Reader." US-China Foreign Language 14, no. 10 (2016): $\quad$ 717-22. https://doi.org/10.17265/15398080/2016.10.007.

Zou, Bin, Hui Li, and Jiaying Li. "Exploring a Curriculum App and a Social Communication App for EFL Learning." Computer Assisted Language Learning 31, no. 7 (2018): 694-713.

https://doi.org/10.1080/09588221.20 18.1438474 . 